\title{
Mechanical Behavior of Polymer Foam Reinforced with Silica Aerogel
}

\author{
Jae-Hyeok Ahn*, Jeong-Hyeon Kim, Jeong-Dae Kim, Sungkyun Park*, \\ Kang Hyun Park ${ }^{* * * *}$ and Jae-Myung Lee* \\ "Department of Naval Architecture and Ocean Engineering, Pusan National University, Busan, Korea \\ * Department of Physics, Pusan National University, Busan, Korea \\ "Nepartment of Chemistry, Pusan National University, Busan, Korea \\ 실리카 에어로겔을 첨가한 폴리머 폼의 기계적 특성
안재혁* 김정현 ${ }^{*}$ 김정대* • 박성균 ${ }^{* *}$ • 박강현 ${ }^{* * *}$ 이제명*
*부산대학교 조선해양공학과
*부산대학교 물리학과
*부산대학교 화학과

KEY WORDS: Polyurethane foam 폴리우레탄 폼, Cryogenic 극저온, Mechanical properties 기계적 특성, Compression behavior 압축 거동, Silica aerogel 실리카 에어로겔

\begin{abstract}
In the present study, silica-aerogel-polyurethane foams were synthesized to improve the mechanical characteristics and insulation performance of the polyurethane foam applied to a liquefied natural gas carrier at a cryogenic temperature of $-163^{\circ} \mathrm{C}$. A silica-aerogel-polyurethane foam bulk was prepared using a homogenizer by varying the weight ratio of the silica aerogel $(0,1,3$, and 5 wt $\%)$, while maintaining the contents of the polyol, isocyanate, and blowing agent constant. Compression tests were performed at room and cryogenic temperatures to compare the mechanical properties of the silica-aerogel polyurethane foams. The internal temperature of the universal testing machine was maintained through the cryogenic chamber. The thermal conductivity of the silica-aerogel-polyurethane foam was measured using a heat flow meter to confirm the insulation performance. In addition, the effect of the silica aerogels on the cells of the polyurethane foam was investigated using FE-SEM and FTIR. From the experimental results, the 1 wt\% silica aerogel polyurethane foam showed outstanding mechanical and thermal performances.
\end{abstract}

\section{1. 서 론}

최근 환경규제 강화로 친환경적 연료인 액화천연가스(Liquefied natural gas, $\mathrm{LNG}$ )의 수요가 증가함에 따라 액화천연가스 운반선 의 수요가 증가하고 있다. 천연가스 혹은 액화천연가스를 운반하 기 위해서는 연료저장탱크 내부의 온도를 유지시킬 수 있는 기술 이 중요하며, 이를 효율적으로 달성하기 위해 단열성능이 우수한 재료를 사용하는 방법이 주로 채택되고 있다(Lee et al., 2016). 액 화천연가스는 통상적으로 $1.1 \mathrm{bar}$ 의 압력과 $-163^{\circ} \mathrm{C}$ 의 극저온 환경 에서 운반되며 이러한 점을 고려하였을 때 액화천연가스 운반선 의 단열시스템 구조에 많이 사용되는 폴리우레탄 폼에 관한 연구 가 다수 보고되었다(Lee et al., 2015). 일반적으로 폴리우레탄 폼 은 소재의 우수성으로 인해 $\mathrm{LNG}$ 연료저장탱크 및 파이프 등 다 양한 분야에 적용되는 대표적인 단열재로 알려져 있으며 무엇보
다도 가격대비 성능이 우수하다는 장점이 있다 (Park et al., 2016b). 폴리우레탄 폼은 고분자 복합재료로서 다공성의 특징을 가지며 재료의 단열성능이 내부 기공의 크기 및 형태에 따라 좌 우되기 때문에 폴리우레탄 폼의 성능 향상을 위한 연구가 계속해 서 진행되고 있다(Modesti et al., 2007; Kim et al., 2016).

폴리우레탄 폼의 기계적 특성 및 단열성능 강화를 목적으로 한 연구 결과를 살펴보면 Han et al.(2010)은 유리섬유강화 폴리 우레탄 폼의 반복충격시험을 통해 $\mathrm{LNG}$ 선박에 작용하는 슬로 싱 하중을 견딜 수 있는 단열시스템에 대한 연구를 수행하였으 며, Yang et al.(2013)은 실리카 에어로겔의 폴리우레탄 멤브레인 에 적용하기 위한 공정 및 적용조건 특성에 대한 연구를 수행 하였다. Lee et al.(2015)은 폴리우레탄 폼에 압축하중을 가하여 기계적 특성을 파악하고 밀도와 같은 기계적 성질에 큰 영향을 미치는 영향변수를 설정하여 구조해석에 필요한 항복강도와 탄

Received 16 August 2017, revised 26 August 2017, accepted 20 December 2017

Corresponding author Jae-Myung Lee: +82-51-510-2342, jaemlee@pusan.ac.kr

(C) 2017, The Korean Society of Ocean Engineers

This is an open access article distributed under the terms of the creative commons attribution non-commercial license (http://creativecommons.org/licenses/by-nc/3.0) which permits unrestricted non-commercial use, distribution, and reproduction in any medium, provided the original work is properly cited. 
성계수를 조사하고 재료 구성 방정식을 제안하였다. 또한 Park et al.(2016a) 은 폴리우레탄 폼에 첨가되는 발포제의 성분이 미 치는 영향에 대해 조사하였으며 성분을 다르게 하여 유리섬유 강화 폴리우레탄 폼의 기계적 특성을 파악하는 연구를 수행하 였다.

그러나 이러한 폴리우레탄 폼에 대한 많은 연구에도 불구하 고 강도 및 단열성능 등에서 문제점들이 제기되고 있다. 따라서 본 연구에서는 기존 폴리우레탄 폼의 단열성능을 더욱 높이고 기계적 강도 또한 강화할 수 있도록 실리카 에어로겔의 사용을 검토하였다. 실리카 에어로겔은 1931년 미국의 Kistler 박사에 의해 처음으로 만들어 졌다(Dorcheh and Abbasi, 2008). 이후, 1980년대에 상업적으로 이용되기 시작하였으며 2011년부터 상 압 건조공법이 개발되어 가격이 하락하면서 여러 다양한 분야 에 연구개발이 이루어지고 있다(Oh and Choi, 2009). 특징으로는 지구상에서 존재하는 가장 가벼운 고체로 알려져 있으며, 실리 카를 기반으로 하는 초다공성 구조를 가지고 있다. 내부공간이 거의 비어 있는 상태로 열차단성과 흡음성이 우수하다. 이러한 장점 때문에 실리카 에어로겔에 대한 많은 연구가 진행되고 있 다. 그러나 실리카 에어로겔을 폴리우레탄 폼에 적용한 연구는 드물며 특히 액화천연가스 운반선의 환경을 고려한 극저온 상 태에서의 기계적 성능 평가는 거의 수행되지 않았다.

본 연구에서는 상온 및 극저온에서의 압축시험을 통해 실리 카 에어로겔을 첨가한 폴리우레탄 폼의 기계적 성능평가를 수 행하여 기존의 폴리우레탄 폼과의 압축강도를 비교하였으며 실 리카 에어로겔의 첨가량에 따른 단열성능을 평가하기 위해 열 전도도를 측정하였다. 또한 FTIR 분석 및 SEM 촬영을 통해 폴 리우레탄 폼과 실리카 에어로겔 사이의 결합을 파악하고 실리 카 에어로겔 폴리우레탄 폼의 미세구조를 분석하여 폼의 셀 구 조 안정성을 평가하였다.

\section{2. 실험 방법}

\section{1 시험편 제조}

본 연구에서 폴리우레탄 폼에 적용한 실리카 에어로겔(REM tech)의 재료물성치는 Table 1에 나타내었다. Table 1에서 볼 수 있듯이 실리카 에어로겔은 $90 \sim 99 \%$ 기공성을 가진 특수소재로 밀 도가 낮고 열전도도가 약 $0.02 \mathrm{~W} / \mathrm{m} \cdot \mathrm{K}$ 이다. 실리카 에어로겔의 우 수한 단열성능 때문에 항공우주산업 및 건축산업등 다양한 분야 에서 널리 적용되고 있다(Kim et al., 2011; Park et al., 2013; Venkataraman et al., 2014).

폴리우레탄 폼을 제작하기 위해 폴리올(Polyol, Korea Polytech corporation), 이소시아네이트(polymeric MDI M20R, Korea Polytech corporation), 발포제(HFC-245fa, Korea Polytech corporation)를 사 용하였다. 본 연구에서 사용된 폴리우레탄 폼은 Polyol, Polymeric $\mathrm{MDI}, \mathrm{HFC}-245 \mathrm{fa}$ 를 1000:1160:50의 비율로 고정하고 실리카 에어 로겔을 첨가하여 Bulk형태의 시험편을 제작하였다. 첫 번째로 실 리카 에어로겔을 균질하게 혼합하기 위해 호모게나이저를 이용 하여 상대적으로 점도가 낮은 Polymeric $\mathrm{MDI}$ 와 충분히 혼합시킨 후, 혼합용액에 Polyol과 HFC-245fa를 넣고 4500rpm에서 약 60초 동안 분산시켜 실리카 에어로겔 폴리우레탄 폼 용액을 만들었다.
Table 1 Property of silica aerogel general data

\begin{tabular}{cc}
\hline \hline \multicolumn{2}{c}{ Silica aerogel powder type general data } \\
\hline Particle size range $[\mu \mathrm{m}]$ & $10 \sim 200$ \\
Pore diameter $[\mathrm{nm}]$ & 20 \\
Pore volume $\left[\mathrm{cm}^{3} / \mathrm{g}\right]$ & $2.2 \sim 2.5$ \\
Bulk density $\left[\mathrm{kg} / \mathrm{m}^{3}\right]$ & $70 \sim 150$ \\
Surface chemistry & Hydrophobic \\
Thermal conductivity $[\mathrm{W} / \mathrm{m} \cdot \mathrm{K}]$ & $0.0018 \sim 0.02$ at $25^{\circ} \mathrm{C}$ \\
Surface area $\left[\mathrm{m}^{2} / \mathrm{g}\right]$ & $300 \sim 350$ \\
Porosity $[\%]$ & $90 \sim 99$ \\
\hline
\end{tabular}

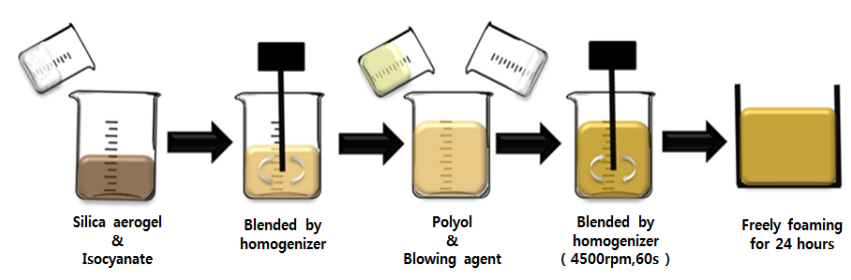

(a)

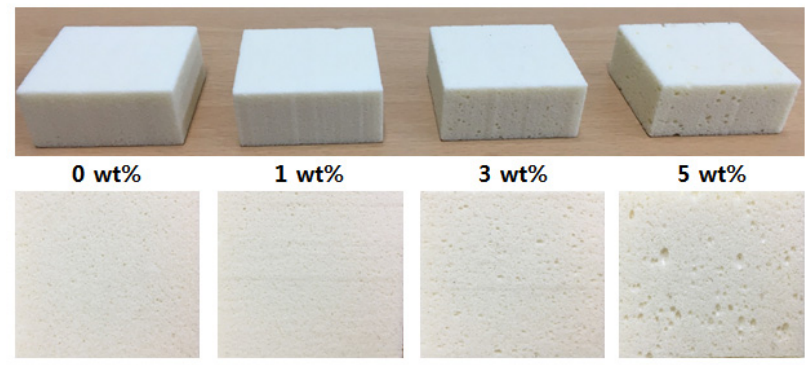

(b)

Fig. 1 (a) Fabrication process of silica aerogel polyurethane foam and (b) surface of silica aerogel polyurethane foam.

그 후 준비된 용액을 개방형 박스형태 틀에 붓고 상온에서 24시 간동안 자연발포를 거쳐 Bulk형태의 실리카 에어로겔 폴리우레 탄 폼을 완성하였으며 Fig. 1 (a)에 제작 과정을 나타내었다. Bulk 형태의 실리카 에어로겔 폴리우레탄 폼은 상온 및 극저온(-16 $3^{\circ} \mathrm{C}$ ) 압축시험을 수행하기 위해 $50 \times 50 \times 25 \mathrm{~mm}$ 크기로 가공하여 시험편을 제작하였으며 제작된 모든 시험편은 기계적 특성평가 를 위해서 한국산업규격(KS M 3809)을 준수하여 제작하였다. Fig. 1 (b)는 가공된 압축 시험편의 형상으로 Silica aerogel을 $0 \%, 1 \%$, $3 \%, 5 \%$ 의 중량비로 첨가한 재료의 측면부를 촬영한 사진이다.

\section{2 특성 평가}

본 연구에서는 한국산업규격(KS M ISO844)을 준수하여 모든 압축시험을 진행하였으며 극저온 압축시험의 경우 내부온도에 대한 열평형을 고려하여 압축시험 챔버 내부의 온도를 $-163^{\circ} \mathrm{C}$ 로 고정하여 약 1 시간 동안 극저온 압축시험 시험편을 예비냉 각 시킨 후 압축 시험을 진행하였다. Table 2는 본 연구의 압축 시험 조건을 나타낸다. 본 연구에서는 실리카 에어로겔과 이소 시아네이트, 폴리올과 발포제를 균질하게 분산하기위해 호모 
Table 2 Compression test temperature condition of sample specimen

\begin{tabular}{ccccc}
\hline \hline Temperature $\left[{ }^{\circ} \mathrm{C}\right]$ & \multicolumn{4}{c}{ Silica aerogel $[\mathrm{wt} \%]$} \\
\hline 20 & 0 & 1 & 3 & 5 \\
-163 & 0 & 1 & 3 & 5 \\
\hline
\end{tabular}

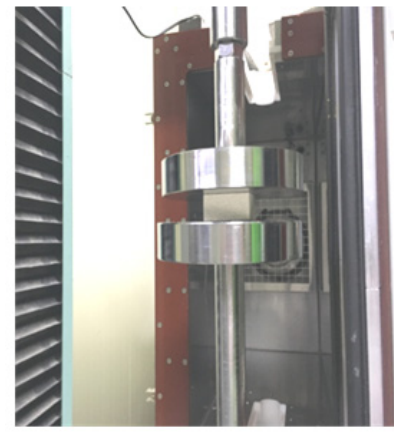

(a)

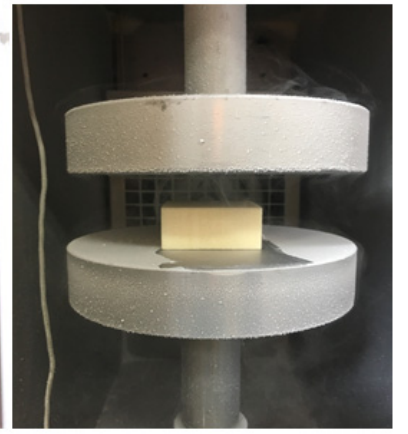

(b)

Fig. 2 Photographs of compression test progress at (a) room temperature and (b) cryogenic temperature

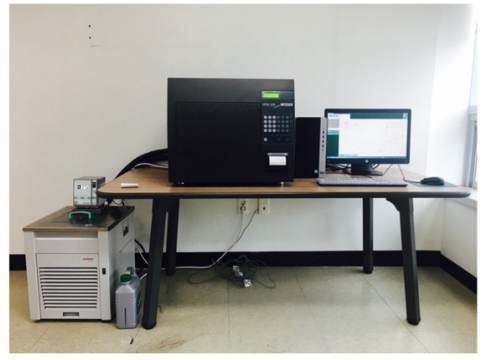

(a)

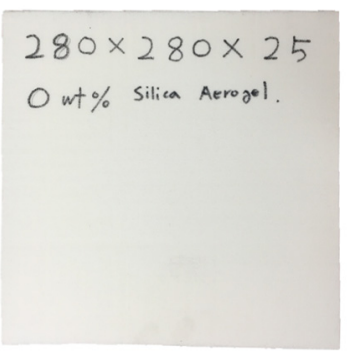

(b)

Fig. 3 (a) Photographs of HFM(heat flow meter) and (b) thermal conductivity test specimen

게나이저(T50-digital ULTRA-TURRAX, IKA)를 사용하였다. 용 액의 발포가 완료되고 가공된 실리카 에어로겔 폴리우레탄 폼 의 시험편 셀 구조 및 형태분석을 위해서 주사전자현미경(FESEM SUPRA25, ZEISS)을 사용하여 미세구조를 관찰하였다. 또 한 상온 및 극저온에서 압축시험을 수행하여 기계적 강도 평가 를 하였으며 만능재료시험기(KSU-5M, 경성시험기(주)에 극저온 용 챔버를 장착하여 사용하였다. 챔버 내부에 액체질소를 분사 하고 자동 온도 조절장치를 이용하여 극저온 환경인 영하 16 $3{ }^{\circ} \mathrm{C}$ 를 유지하며 압축시험을 진행하였다. Fig. 2 (a)는 상온 압축 시험을 Fig. 2 (b)에서는 극저온 압축시험을 나타낸다.

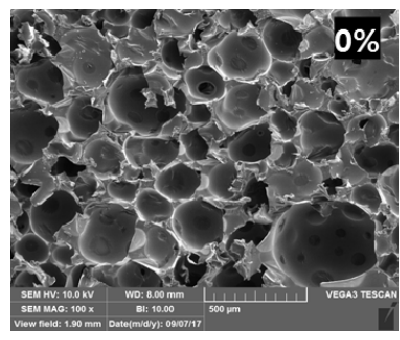

(a) $0 \mathrm{wt} \%$

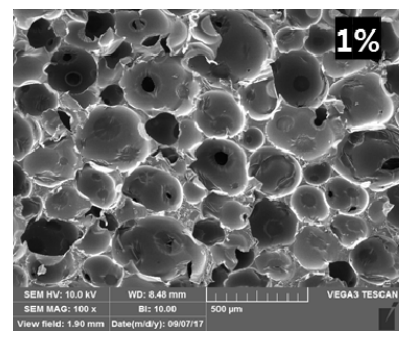

(b) $1 \mathrm{wt} \%$

본 연구에서는 실리카 에어로겔을 첨가한 폴리우레탄 폼의 단열성능을 확인하기 위해 열전도도를 측정하였다. 열전도도 측정을 위해 Heat flow meter(HFM, NETZSCH)를 사용하였고 Fig. 3은 $\mathrm{HFM}$ (Heat flow meter) 장비 사진을 나타낸다.

압축시험을 수행한 시험편과 동일한 실리카 에어로겔 폴리우 레탄 폼의 Bulk에서 시료크기 $280 \times 280 \times 25 \mathrm{~mm}$ 으로 열전도도 시 험편을 가공하여 상온에서 열전도도 값을 측정하였다.

\section{3. 실험결과}

\section{1 미세구조 분석}

실리카 에어로겔이 폴리우레탄 폼의 셀 형성에 미치는 영향 을 분석하기 위해서 주사현미경을 통해 관찰하였다. Fig. 4는 발 포방향에 대한 폴리우레탄 폼의 샘플을 촬영한 것이다. 중량비 가 비교적 낮은 경우에서 폴리우레탄 폼의 셀 크기가 일정하고 안정적이며 셀 형태도 닫힌 형태를 보이는 것을 확인하였다. 중 량비가 증가할수록 셀은 크기가 일정하지 않으며 셀 형태 또한 불규칙적이고 셀이 파괴되는 현상을 보였다. 그러나 중량비 증 가에 따라서 비례적으로 셀 크기나 형태가 변화된다고 판단하 기는 어렵지만 $3 \mathrm{wt} \%$ 이상 실리카 에어로겔을 첨가하면 셀 구조 및 형태가 파괴됨을 확인할 수 있었다. Table 3은 FE-SEM을 통 해 셀의 평균 크기를 측정한 결과를 나타낸다. 셀의 평균크기는 점차적으로 증가하지만 $1 \mathrm{wt} \%$ 의 경우 최소 크기와 최대 크기의 차이가 크지 않고 셀의 형태 및 크기가 다른 중량비에 비해 일 정한 것을 확인할 수 있으며 이를 통해 $1 \mathrm{wt} \%$ 에서의 단열성능 효과가 크게 나타나는 것으로 판단된다. 셀의 크기가 작고 형태 및 분포가 균일할수록 단열성능이 향상되는데 $0 \mathrm{wt} \%$ 와 $1 \mathrm{wt} \%$ 에 서 단열성능은 기존의 폴리우레탄 폼의 셀 사이에 있던 공기층 보다 단열성능이 뛰어난 실리카 에어로겔이 사용되면서 열전달 을 방해하며 셀의 크기 역시 기존의 폴리우레탄 폼 보다 크기 가 증가하여 차이가 발생하는 것으로 판단된다. $3 \mathrm{wt} \%$ 와 $5 \mathrm{wt} \%$ 에서는 미세구조를 확인한 결과 셀의 크기는 증가한 반면 셀이 파괴되거나 열이 전달될 수 있는 기공이 발생하여 단열성능이 저하된 것으로 보인다.

이는 과거 연구보고에 따르면 실리카 에어로겔 같은 초미세 입자는 일종의 충진제 역할을 하여 셀을 더 조밀하고 균일하게 구성하게 하지만 과량으로 첨가되었을 때 폴리우레탄 폼과의 분산성이 떨어지게 되고 결국 셀 형성에서 기존 폴리우레탄 폼 의 셀보다 일정하고 닫힌 형태의 셀을 형성하기 어렵게 된다는 보고가 있다(Park et al., 2016). 또 다른 연구에 의하면 셀 형성 시 첨가제의 양, 분산관계는 폴리우레탄 폼의 밀도에도 큰 영향

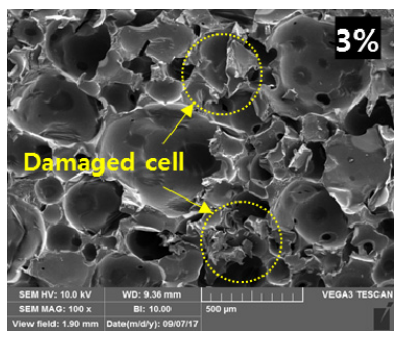

(c) $3 \mathrm{wt} \%$

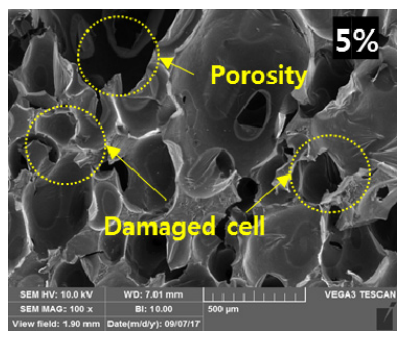

(d) $5 \%$

Fig. 4 Cell shape and structure of the silica aerogel polyurethane foam, depending on wt $\%$ of silica aerogel 
Table 3 Cell size of silica aerogel polyurethane foam

\begin{tabular}{cccc}
\hline \hline Silica aerogel $[\mathrm{wt} \%]$ & Average cell size $[\mu \mathrm{m}]$ & Minimum cell size $[\mu \mathrm{m}]$ & Maximum cell size $[\mu \mathrm{m}]$ \\
\hline 0 & $124 \pm 59$ & 30 & 360 \\
1 & $175 \pm 59$ & 80 & 353 \\
3 & $198 \pm 74$ & 70 & 520 \\
5 & $207 \pm 91$ & 75 & 574 \\
\hline
\end{tabular}

을 미치고 특히 첨가제의 분산성이 좋지 못한 경우 전체적인 밀도가 일정하지 않거나 균일한 형태의 셀을 형성하기 어렵게 된다는 연구 보고가 있다(Dorcheh and Abbasi, 2008). 따라서 첨 가제인 실리카 에어로겔의 중량비가 높아질수록 폴리우레탄 폼 과의 분산성이 떨어져서 $3 \mathrm{wt} \%, 5 \mathrm{wt} \%$ 의 경우에서 셀이 파괴되 거나 균일하지 않은 현상이 일어나는 것을 확인할 수 있다.

\section{2 열전도도}

$\mathrm{HFM}$ 을 통해 단열성능이 우수한 실리카 에어로겔을 첨가했을 때 중량비가 증가함에 따라서 열전도도는 높아지는 대신 기계 적 성능은 약화될 것이라고 예상하였다. 그러나 실리카 에어로 겔의 첨가량이 증가할수록 오히려 기존 폴리우레탄 폼의 열전 도도보다 더 높은 열전도도를 보여 단열성능이 하락하였으며 Table 4에 측정된 열전도도 값을 표시하였다. 그러나 $1 \mathrm{wt} \%$ 에서 는 단열성능이 향상되어 첨가량에 따라서 비례적으로 단열성능 이 향상되는 것이 아님을 확인할 수 있었고 실리카 에어로겔을 $1 \mathrm{wt} \%$ 첨가한 폴리우레탄 폼에서 가장 우수한 단열성능을 나타 내었다. 이는 SEM 촬영을 통해 알 수 있듯이 중량비가 증가할 수록 셀의 크기 및 형태가 균일하지 못하여 열전도도에 영향을 미치는 것으로 판단된다.

\subsection{ATR-FTIR 분석}

본 연구에서는 적외선을 통해 진동을 흡수하여 스펙트럼의 형
태로 나타내는 ATR-FTIR 분광법을 사용하여 재료의 배향 및 결 정형태등 구조 변화를 확인하였다. Fig. 5에 실리카 에어로겔을 첨가한 폴리우레탄 폼의 FTIR 스펙트럼 결과를 표시하였다. 공통 적으로 폴리우레탄 폼에 의해 나타난 Peak점은 $1720 \mathrm{~cm}^{-1}$, $1530 \mathrm{~cm}^{-1}, 1230 \mathrm{~cm}^{-1}, 1070 \mathrm{~cm}^{-1}$ 으로 나타난다. 폴리우레탄 폼은 우 레탄 결합(Urethane Bond)인 - $\mathrm{OH}$ 활성 수산기와 이소시아네이트 에서의 $-\mathrm{N}=\mathrm{C}=\mathrm{O}$ 인 이소시아네이트기(Isocyanate Group)가 반응하 여 열을 발생시키면서 형성된다. 이 때 -NHCOO-의 구조를 가진 화합물을 생성시키는데, 1000 이상의 분자가 결합된 상태를 폴리 우레탄 폼이라고 한다. FTIR 분석결과 공통적인 Peak점에서 폴리 우레탄 결합의 형태를 볼 수 있다. 먼저 $1720 \mathrm{~cm}^{-1}$ 에서는 $\mathrm{C}=\mathrm{O}$ stretching vibrations, $1530 \mathrm{~cm}^{-1}$ 에서는 $\mathrm{N}-\mathrm{H}$ bending vibrations, $1230 \mathrm{~cm}^{-1}$ 은 C-O-C stretching vibrations 의 Peak를 확인할 수 있었고 $1070 \mathrm{~cm}^{-1}$ 에서는 C-O-C antisymetric stretching vibrations을 나타내 었다. 실리카 에어로겔을 첨가한 $1 \mathrm{wt} \%$ 와 $3 \mathrm{wt} \%$ 에서는 공통적으로 나타난 Peak의 형태 및 길이가 증가하다가 $5 \mathrm{wt} \%$ 이상이 되면 감 소하는 것을 확인하였다. 또한 $0 \mathrm{wt} \%$ 와 비교하였을 때 $3750 \mathrm{~cm}^{-1}$ 에 서의 -OH stretching vibrations의 Peak의 길이가 $0 \mathrm{wt} \%$ 보다 더 크게 나타났고 실리카 에어로겔의 주성분인 $\mathrm{SIO}_{2}$ 성분으로 인한 Peak 점은 $2930 \mathrm{~cm}^{-1}$ 에서 $\mathrm{SI}_{-} \mathrm{CH}_{3}$ 결합을 통해 차이를 확인할 수 있었다.

\section{4 압축시험 결과}

압축시험을 통해 응력-변형률 관계에 대한 실험의 신뢰성 및

Table 4 Thermal conductivity of silica aerogel polyurethane foam at a temperature of $20^{\circ} \mathrm{C}$

\begin{tabular}{cccc}
\hline \hline Temperature $\left[{ }^{\circ} \mathrm{C}\right]$ & Silica aerogel $[\mathrm{wt} \%]$ & Thermal conductivity $[\mathrm{W} / \mathrm{m} \cdot \mathrm{K}]$ & density $\left[\mathrm{kg} / \mathrm{m}^{3}\right]$ \\
\hline & 0 & 0.03020 & 140.31 \\
20 & 1 & 0.02676 & 167.79 \\
& 3 & 0.03109 & 153.51 \\
& 5 & 0.03414 & 130.84 \\
\hline
\end{tabular}

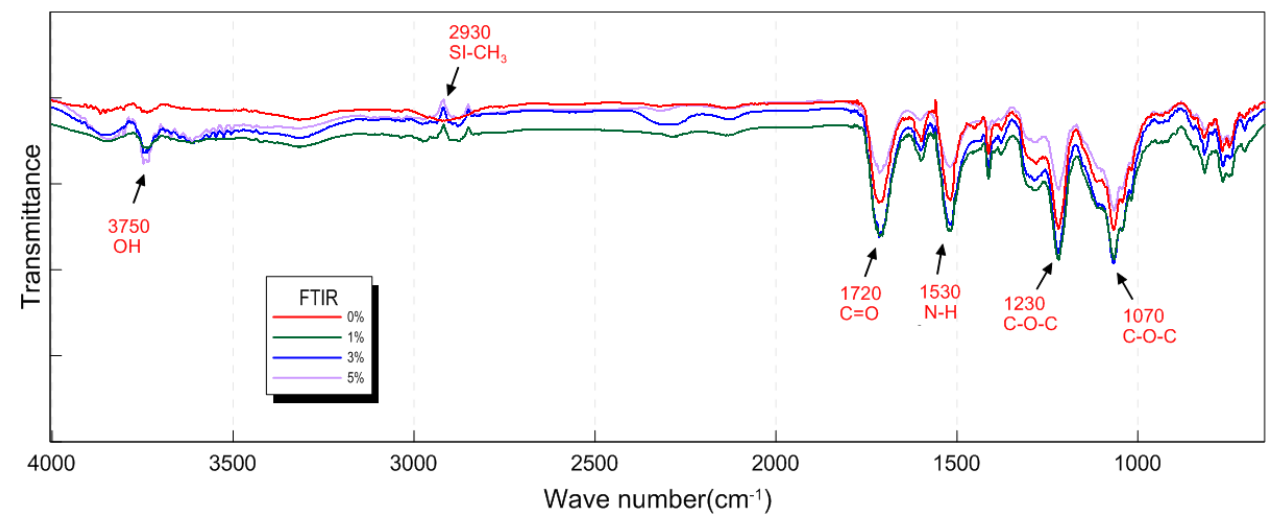

Fig. 5 ATR-FTIR peak analysis of silica aerogel polyurethane foams 


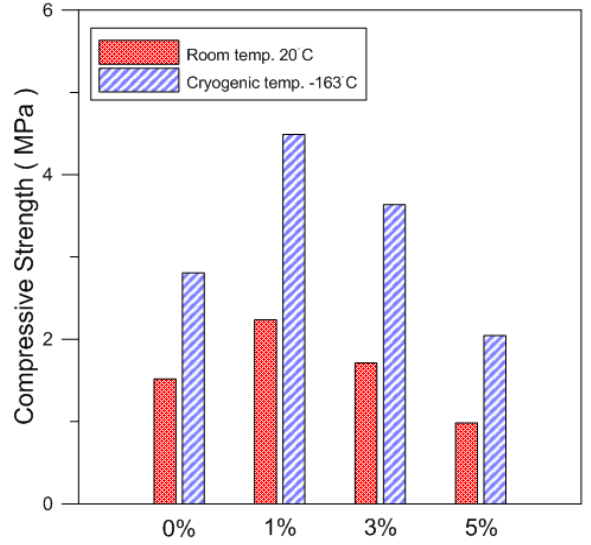

(a)

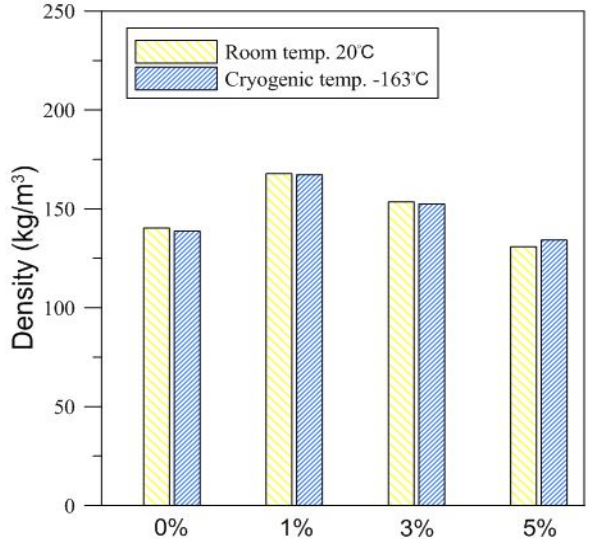

(b)

Fig. 6 (a) Compressive strength of silica aerogel PUF, (b) density of silica aerogel PUF comparisons
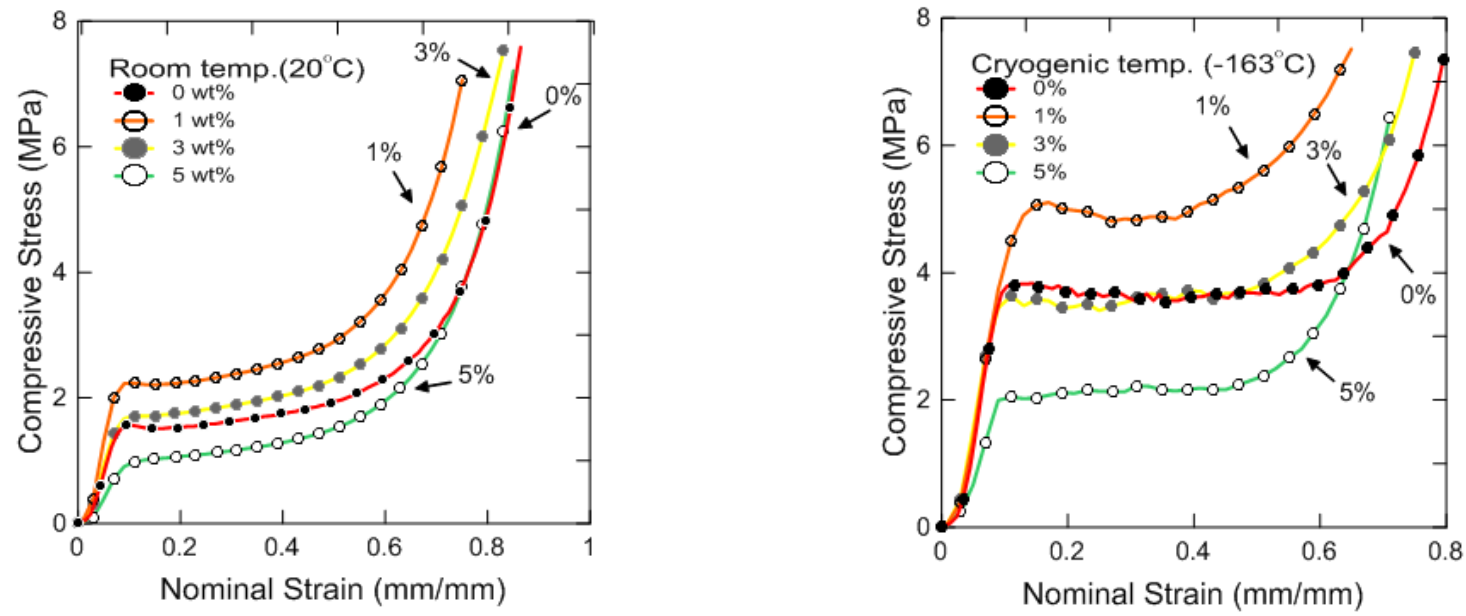

Fig. 7 Compression test results of silica aerogel polyurethane foam under the identical conditions

재현성을 확보하기 위해서 동일한 압축시험 조건 당 총 4번의 반 복시험을 통해 평균에 가장 근접한 데이터를 해당 조건의 대표값 으로 결정하였다. Table 4는 해당 조건의 대표값에 대한 압축시험 결과 및 해당 시험편의 밀도를 나타낸다. 중량비와 온도에 대한 압축강도의 경향성을 파악하기 위해 Fig. 6 (a)에 경향성을 나타 내는 그래프를 표시하였다. 또한 재료의 밀도를 고려하기 위해서 Fig. 6 (b)에 중량비 별 밀도를 표시하였다. 경향성을 살펴보면 $1 \mathrm{wt} \%$ 를 기준으로 모두 압축강도가 감소하는 경향을 보였으며 밀 도 또한 압축강도와 유사한 경향을 보였다. Fig. 7은 상온과 극저 온에서 압축강도를 비교하기 위해서 각 시편의 밀도를 고려하여 중량비에 따라 응력-변형률 선도를 나타낸 것이다. 상온 및 극저 온에서 기존 폴리우레탄 폼인 $0 \mathrm{wt} \%$ 보다 $1 \mathrm{wt} \%$ 가 모두 압축강도 가 높은 결과를 보였다. $1 \mathrm{wt} \%$ 의 경우 $0 \mathrm{wt} \%$ 대비 상온에서 $63.997 \%$, 극저온에서 $37.454 \%$ 증가하는 것을 알 수 있었다.

그러나 $1 \mathrm{wt} \%$ 에서는 압축강도가 증가하는 반면 $3 \mathrm{wt} \%$ 와 $5 \mathrm{wt} \%$ 에서는 압축강도가 오히려 감소하는 경향을 확인할 수 있었다. 과거 연구를 보면 실리카 에어로겔 첨가제는 폴리우레탄 폼의 핵 생성제 역할을 수행하여 균일한 셀을 형성시키고 셀의 양을 증가 시키는 역할을 하지만 $3 \mathrm{wt} \%$ 이상으로 과도하게 첨가되게 되면 용액의 점도가 높아져 분산을 어렵게하고 균질한 셀 형성을 방해
한다. 이를 통해 $3 \mathrm{wt} \%$ 와 $5 \mathrm{wt} \%$ 에서는 폴리우레탄 폼과의 분산관 계가 악화되어 셀이 붕괴되는 현상이 더욱 심해져 강도가 감소하 는 것으로 사료된다(Nazeran and Moghaddas, 2017; Zhao et al., 2015).

\section{4. 결 론}

본 연구에서는 실리카 에어로겔이 폴리우레탄 폼의 기계적, 단열성능에 미치는 영향을 분석하기 위해서 중량비에 따른 실 리카 에어로겔 폴리우레탄 폼을 제작 및 합성하여 압축시험을 통해 재료의 거동을 파악하였으며 미세구조를 파악하기 위해 FE-SEM 촬영을 통해 셀 구조를 확인하였다. 본 연구의 주요 결 과는 아래에 요약되었다.

(1) 실리카 에어로겔을 첨가한 폴리우레탄 폼을 기존 폴리우 레탄 폼인 $0 \mathrm{wt} \%$ 를 포함하여 $1 \mathrm{wt} \%, 3 \mathrm{wt} \%, 5 \mathrm{wt} \%$ 까지 실리카 에 어로겔 폴리우레탄 폼을 제작한 결과, $1 \mathrm{wt} \%$ 에서의 압축강도가 상온에서 $2.2354 \mathrm{Mpa}$, 극저온에서 $4.4884 \mathrm{Mpa}$ 로 가장 높은 기계 적 거동을 보였다.

(2) 실리카 에어로겔을 $1 \mathrm{wt} \%$ 첨가했을 때, 다른 구조에 비해 안정적이고 균질한 셀 구조를 보이며 셀 모양 또한 상대적으로 
일정하고 닫힌 형태로 존재하였다. 그러나 $1 \mathrm{wt} \%$ 이상으로 실리 카 에어로겔을 첨가한 경우 폴리우레탄 폼 용액과의 분산성이 감소하여 온전한 셀 형태를 유지하지 못하고 셀이 파괴되거나 크기가 균일하지 않게 되는 것을 확인할 수 있었다.

(3) 실리카 에어로겔의 첨가량에 따라 비례적으로 열전도도가 감소하는 것이 아님을 확인할 수 있었고 오히려 첨가량이 많아 질수록 단열성능이 감소하는 현상을 보였다. 그러나 $1 \mathrm{wt} \%$ 에서 는 단열성능이 향상되어 이를 통해 $1 \mathrm{wt} \%$ 이하의 실리카 에어로 겔 첨가는 기존 폴리우레탄 폼의 단열성능을 향상시킴을 확인 하였다.

\section{후기}

이 논문은 부산대학교 기본연구지원사업(2년)에 의하여 연구 되었음.

\section{References}

Dorcheh, A.S., Abbasi, M.H., 2008. Silica Aerogel; Synthesis, Properties and Characterization. Journal of Materials Processing Technology, 199(1), 10-26.

Han, D.S., Park, I.B., Kim, M.H., Noh, B.J., Kim, W.S., Lee, J.M., 2010. The Effects of Glass Fiber Reinforcement on the Mechanical Behavior of Polyurethane Foam. Journal of Mechanical Science and Technology, 24(1), 263-266.

Kim, S.K., Kim, J.H., Lee, J.H., Park, S.B., Lee, J.M., 2016. Comparative Study on Mechanical Behavior after Deformation Recovery of Polymeric Foam for Ships and Offshore Structures. Journal of the Society of Naval Architects of Korea, 53(3), 195-200.

Kim, N.H., Hwang, H.S., Park, I., 2011. Facile Preparation of Nanoporous Silica Aerogel Granules. Applied Chemistry for Engineering, 22(2), 209-213.

Lee, J.H., Kim, S.K., Lee, J.M., 2016. Temperature-Dependent ViscoplasticDamage Constitutive Model for Nonlinear Compressive Behavior of Polyurethane Foam. Journal of the Computational Structural Engineering Institute of Korea, 29(5), 437-445
Lee, J.H., Park, S.B., Kim, S.K., Bang, C.S, Lee, J.M., 2015. Modified Gurson Model to Describe Non-linear Compressive Behavior of Polyurethane Foam with Considering Density Effect. Journal of the Computational Structural Engineering Institute of Korea, 28(5), 543-551

Modesti, M., Lorenzetti, A., Besco, S., 2007. Influence of Nanofillers on Thermal Insulating Properties of Polyurethane Nanocomposites Foams, Polymer Engineering \& Science, 47(9), 1351-1358.

Nazeran, N., Moghaddas, J., 2017. Synthesis and Characterization of Silica Aerogel Reinforced Rigid Polyurethane Foam for Thermal Insulation Application. Journal of Non-Crystalline Solids, 461(1), 1-1.

Oh, K.W., Choi, H.W., 2009. Acoustic Characteristics of Ultra-porous Aerogel/Fiber Composite Materials. Textile Science and Engineering, 46(1), 48-54.

Park, S.B., Lee, C.S., Choi, S.W., Kim, J.H., Bang, C.S., Lee, J.M., $2016 \mathrm{a}$ Polymeric Foams for Cryogenic Temperature Application: Temperature Range for Non-Recovery and Brittle-Fracture of Microstructure. Composite Structures, 136, 258-269.

Park, S.B., Choi, S.W., Kim, J.H., Bang, C.S., Lee, J.M., 2016b. Effect of the Blowing Agent on the Low-Temperature Mechanical Properties of CO2- and HFC-245fa-Blown glass-Fiber-Reinforced Polyurethane Foams. Composites Part B, 93, 317-327.

Park, K.W., Lee, Y., Yoon, J.K., Koo, K.W., 2013. A Study on Physical Characteristics of Silica Aerogel/Polymer Composite Materials. The Transactions of The Korean Institute of Electrical Engineers, 62(9), 1318-1323.

Venkataraman, M., Mishra, R., Militky, J., Hes, L., 2014. Aerogel Based Nanoporous Fibrous Materials for Thermal Insulation. Fibers and Polymers, 15(7), 1444-1449.

Yang, J.H., Yoon, S.H., Jeong, C.H., Min, M.H., Kim, T.K, 2013. Application Properties of Ultra Light Weight Silica Aerogel to Polyurethane Membrane. Textile Coloration and Finishing, 25(4), 279-286.

Zhao, C., Yan, Y., Hu, Z., Li, L., Fan, X., 2015. Preparation and Characterization of Granular Silica Aerogel/Polyiso Cyanurate Rigid Foam Composites. Construction and Building Materials, 93(15), 309-316. 